Original scientific paper - Izvorni znanstveni rad

UDK: 637.043

\title{
Plasma and milk fatty acid composition as a response to dietary n-3 fatty acids and selenium in periparturient Holstein cows
}

doi: $10.15567 / \mathrm{mljekarstvo.2017.0204}$

\author{
Mislav Đidara ${ }^{*}$, Marcela Šperanda ${ }^{1}$, Matija Domaćinović ${ }^{1}$, Josip Novoselec ${ }^{1}$, \\ Tomislav Mašek , Mirta Balenović ${ }^{3}$, Nina Poljičak Milas ${ }^{4}$, Neška Vukšić ${ }^{1}$ \\ ${ }^{1}$ Josip Juraj Strossmayer University, Faculty of Agriculture in Osijek, Department of Animal Husbandry, \\ P. Svačića 1D, 31000 Osijek, Croatia \\ ${ }^{2}$ University of Zagreb, Veterinary Faculty, Department of Animal Nutritionand Dietetics, \\ Heinzelova 55, 10000 Zagreb, Croatia \\ ${ }^{3}$ Croatian Veterinary Institute, Poultry Centre, Heinzelova 55, 10000 Zagreb, Croatia \\ ${ }^{4}$ University of Zagreb, Veterinary Faculty, Department of Pathophysiology, \\ Heinzelova 55, 10000 Zagreb, Croatia \\ Received - Prispjelo: 06.09.2016. \\ Accepted - Prihvaćeno: 21.03.2017.
}

\begin{abstract}
Linseed is well known for abundant content of $\alpha$-linolenic acid why it has been widely used as a source of n-3 fatty acid. Higher ratio of polyunsaturated fatty acids can increase lipid peroxidation. Selenium (Se) plays a key role in antioxidant enzymes and can therefore be regarded for use in attempts focused on protection of fatty acids from oxidation. The organic Se has been shown to have higher bioavailability compared to the inorganic selenium. The aim of this research was to determine the influence of dietary replacement of $n-6$ with $n-3$ polyunsaturated fatty acids on plasma and milk fatty acid composition in the dairy cows. The experiment was conducted on 30 dairy Holstein cows in the period from parturition until the $3^{\text {rd }}$ week of lactation. Soybean meal from control (C) group was replaced with grounded linseed in the both experimental (LS and LS+Se) groups. In addition to that, in the $2^{\text {nd }}$ experimental (LS $+\mathrm{Se}$ ) group sodium selenite from premix was replaced with organic selenium. Blood and milk samples were collected at $21^{\text {st }}$ day of lactation and fatty acids were determined using gas chromatography from it. Feeding dairy cows during transition period with linseed showed a positive impact on milk fatty acid composition by increasing $(\mathrm{P}<0.05)$ the proportion of $\mathrm{n}-3$ fatty acids. Proportion of $\alpha$-linolenic fatty acid increased $(\mathrm{P}<0.05)$ in the blood of both groups fed with linseed, but was significant $(\mathrm{P}<0.05)$ only in milk of $\mathrm{LS}+$ Se group. Such data indicated that the addition of organic selenium acted favourable on $\alpha$-linolenic fatty acid increase in milk. During early postpartum period addition of linseed in meal of dairy cow's increased $(\mathrm{P}<0.05)$ ratio of oleic acid, but in combination with organic source of selenium this increase was not evident $(P>0.05)$.
\end{abstract}

Key words: dairy cows, linseed, fatty acids, milk composition

\section{Introduction}

Recent studies have been trying to determine to what extent saturated fatty acid were beneficial for the human health. Haug et al. (2007) determined benefits of $n-3$ polyunsaturated fatty acids (PUFA) for human health. Since milk and milk products represent a substantial portion of fat source for hu- mans, it would be beneficial to increase their $n-3$ fatty acids content (G antner et al. 2015). In recent years extensive research has been focused on the effect of feed rich in $n-3$ polyunsaturated fatty acids (PUFA) on milk fatty acid composition. Linseed as a source of $n-3$ fatty acids was widely used since it is well known for abundant contents of $\alpha$-linolenic 
acid (Scholljegerdes et al., 2014). The addition of linseed in dairy cow's diet changes milk fatty composition by decreasing the ratio of saturated fatty acids and increasing the ratio of mono and polyunsaturated fatty acids. Up to a threefold increase of $\alpha$-linolenic acid was observed in the milk of cows fed with a dietary addition of linseed (Moallem, 2009). The mechanism of bacterial fatty acids saturation in rumen disturbs increment of unsaturated fatty acids in milk (Lourenço et al., 2010). Selenium (Se) plays a key role in antioxidant enzymes (Antunović et al., 2013) and it is known that Se deficiency affects the lipid concentration and fatty acid composition in liver (Schäfer et al., 2004). Selenium as a part of a selenoenzyme type I iodothyronine deiodinase, which is responsible for the majority of peripheral conversions of thyroxine $\left(\mathrm{T}_{4}\right)$ to the active form 3,3',5-triiodothyronine $\left(\mathrm{T}_{3}\right)$. Selenoenzymes may modulate or control many aspects of the thyroid hormone metabolism such as the iodination of thyroglobulin in the thyroid gland, the peripheral synthesis of $T_{3}$ from $T_{4}$, the degradation of $T_{4}$ to $3,3^{\prime}, 5^{\prime}$-triiodothyronine, the inactivation of $T_{3}$ to 3,3'-diiodothyronine and the regulation of thyroidal activity by the pituitary-hypothalamic axis. The dietary supplementation of inorganic forms, such as selenite and selenide, could result in toxicity, interaction with other minerals, and relatively poor absorption by the intestinal tract and subsequent less retention of Se in the body (Chung et al., 2007). On contrary, it has been established that organic Se has a higher bioavailability than the inorganic selenium. The aims of the research were to increase the ratio of $\alpha$-linolenic acid in milk by replacing part of the soybean meal with grounded linseed, and to test the effect of replacing dietary inorganic source of selenium with organic source on fatty acid composition in milk.

\section{Material and methods}

\section{Experimental design and diets}

The experiment was conducted on a 30 second parity Holstein dairy cows, body weight of approximately $635 \mathrm{~kg}$, at the age of 3 years, during the first 3 weeks of lactation. The cows were randomly allocated into three groups of 10 cows in separated pens, under same environmental conditions. In this experimental design a part of dietary n- 6 fatty acids in control group (C) was replaced with n-3 fatty acids in two experimental (LS and LS+Se) groups keeping the diets iso-energetic and iso-nitrogenous. All cows were fed with the total mix ration (TMR) which was offered to cows ad libitum and they were fed once a day. The diet was based on $16.00 \%$ of crude protein (CP) and net energy for lactation (NEL) 6.59, 6.53 and $6.52 \mathrm{MJ} / \mathrm{kg}$ DM. TMR was composed of corn silage $8.4 \mathrm{~kg} \mathrm{DM}$, grass silage $5 \mathrm{~kg} \mathrm{DM}$, grass hay $0.85 \mathrm{~kg} \mathrm{DM}$, wet beet pulp $1.7 \mathrm{~kg} \mathrm{DM}$, concentrate $9.57 \mathrm{~kg} \mathrm{DM}$ per cow per day. Concentrate for the control (C) group contained ground corn, sunflower, barley, mineral premix and toasted soy which was replaced with $19 \%$ ground linseed in the experimental (LS and LS +Se) groups (Table 1). In addition to that, in the experimental (LS $+\mathrm{Se}$ ) group sodium selenite from premix was replaced with organic selenium (B-Traxim ${ }^{\circledR}$, Pancosma, Switzerland). Chemical and fatty acid composition of the experimental diets according to the study design are shown in Table 2. Experimental and animal management procedures were conducted in accordance with the "Directive for the Protection of Vertebrate Animals used for Experimental and other Purposes" (86/609/EEC).

Table 1. Composition of the concentrate part of the diet containing no linseed, linseed and linseed supplemented with selenium

\begin{tabular}{cccc}
\hline & \multicolumn{3}{c}{ Groups } \\
\hline Ingredients, \% & $\mathrm{C}$ & LS & LS+Se \\
\hline Corn & 50 & 45 & 45 \\
\hline Barley & 12.2 & 17.5 & 17.5 \\
\hline Wheat bran & 4.5 & - & - \\
\hline Soy toasted & 25.5 & 8 & 8 \\
\hline Urea (Benural) & 0.5 & 1 & 1 \\
\hline Sunflower cake & 2 & 4 & 4 \\
\hline Linseed & - & 19 & 19 \\
\hline Limestone & 2 & 2 & 2 \\
\hline Premix for cows & 0.5 & 0.5 & 0.5 \\
\hline Salt & 2 & 2 & 2 \\
\hline Phosphonal & 0.8 & 1 & 1 \\
\hline Selenium & $0.3^{*}$ & $0.3^{*}$ & $0.3^{+}$ \\
\hline NEL MJ/kg DM & 8.04 & 7.43 & 7.45 \\
\hline Contro group, LS & &
\end{tabular}

C - Control group, LS - Linseed group, LS +Se - Linseed + Selenium group

*Sodium selenite; + B-Traxim ${ }^{\circledR}$ 


\section{Chemical analyses of diets}

The analyses of the diets were carried out in a duplicate using the AOAC (2000) methods in order to determine the dry matter (934.01), the nitrogen content and the crude protein content by destruction in block (992.23), the crude fibre by a Ceramic fibre filter method (962.09) and fat by the Soxhlet method (991.36 AOAC, 1995).

\section{Analyses of milk, plasma and diets fatty acid composition}

Milk and blood samples from each cow were collected on the $21^{\text {st }}$ day of lactation. Blood was collected from the coccygeal vein into tubes with heparin as anticoagulant (Becton Dickinson, Plymouth, UK). Blood was centrifuged at $1500 \mathrm{~g} / 10 \mathrm{~min}$ and plasma was separated and freezed at $-80{ }^{\circ} \mathrm{C}$ until further analyses. A sample of morning and evening milking on the $21^{\text {st }}$ day of lactation was mixed and freezed at $-80{ }^{\circ} \mathrm{C}$ until further analyses. For the

Table 2. Chemical and fatty acid composition of the experimental diets containing no linseed, linseed and linseed supplemented with selenium

\begin{tabular}{cccc}
\hline & \multicolumn{3}{c}{ Groups } \\
\cline { 2 - 4 } & C & LS & LS +Se \\
\hline Dry matter, \% & 36.5 & 36.4 & 36 \\
\hline
\end{tabular}

\begin{tabular}{|c|c|c|c|}
\hline $\begin{array}{c}\text { Chemical composition, } \\
\text { \% DM }\end{array}$ & & & \\
\hline Crude protein $(\mathrm{CP})$ & 15.8 & 16.3 & 16.4 \\
\hline Crude fibre $(\mathrm{CF})$ & 22.4 & 19.5 & 20.7 \\
\hline Fat & 2.1 & 2.3 & 2 \\
\hline Ash & 7.8 & 8.9 & 8.6 \\
\hline $\mathrm{NFE}^{2}$ & 51.9 & 53.0 & 52.3 \\
\hline $\begin{array}{c}\text { Fatty acids, } \\
\% \text { of total fatty acids }\end{array}$ & & & \\
\hline Cl6:0 & 19.3 & 24.0 & 22.8 \\
\hline C18:0 & 3.5 & 4.3 & 4.3 \\
\hline C18:ln-9 & 17.4 & 16.9 & 17.7 \\
\hline $\mathrm{C} 18: 2 \mathrm{n}-6$ & 46.0 & 38.5 & 39.6 \\
\hline $\mathrm{C} 18: 3 n-3$ & 13.8 & 16.3 & 15.6 \\
\hline
\end{tabular}

C - Control group, LS - Linseed group, LS + Se - Linseed + Selenium group

${ }^{2} \mathrm{NFE}$ - Nitrogen-free extract - consisting of carbohydrates, sugars, starches and hemicellulose analyses of fatty acid composition total lipid extraction was done with a hexane-isopropanol 3:2 solution. Glycerides were methyl-esterified to the corresponding methyl esters of fatty acids by a solution of boron trifluoride in methanol (Rule, 1997). The injector temperature was set up to $250{ }^{\circ} \mathrm{C}$, and $1 \mu \mathrm{L}$ of each sample was injected with a split proportion of 1:15. Helium was used as the carrier gas, and the detector temperature was set at $300{ }^{\circ} \mathrm{C}$. The oven program was set as: temperature set at $60{ }^{\circ} \mathrm{C}$ for $2 \mathrm{~min}$, then increased at the rate of $13^{\circ} \mathrm{C} / \mathrm{min}$ up to $150{ }^{\circ} \mathrm{C}$, then increased at $2^{\circ} \mathrm{C} / \mathrm{min}$ up to $220^{\circ} \mathrm{C}$ and held for $10 \mathrm{~min}$, then increased at $2{ }^{\circ} \mathrm{C} / \mathrm{min}$ up to $240{ }^{\circ} \mathrm{C}$ and held for $10{ }^{\circ} \mathrm{C}$. The analysis of fatty acid composition was performed by Shimadzu GC-MS QP2010 Ultra Gas Chromatograph Mass Spectrometer (Shimadzu, Kyoto, Japan), equipped with capillary column ZB WAX (Phenomenex, CA, USA). The results were expressed as a proportion of each individual fatty acid to total fatty acids.

\section{Statistical analysis}

A general linear model (GLM) procedure was used to generate LSD ANOVA (StatSoft, Inc., STATISTICA version 12, USA). The GLM model included fixed effects of the group to determine any significant differences between milk and plasma fatty acid ratio. In case of significance in variation $(\mathrm{P}<0.05)$, Fisher's post hoc test was performed to determine differences between groups.

\section{Results and discussion}

\section{Plasma fatty acid composition}

The proportions of plasma fatty acids on the $21^{\text {st }}$ day of lactation are presented in Table 3. Ratio of n-3 fatty acids in LS and LS + Se groups was higher $(\mathrm{P}<0.05)$ compared to the $\mathrm{C}$ group. This was due to the increase $(\mathrm{P}<0.05)$ of $\alpha$-linolenic $(\mathrm{C} 18: 3 n-3)$ and eicosapentaenoic (C20:5n-3) acids in LS and LS+Se groups compared to the $\mathrm{C}$ group. As a consequence of higher n-3 fatty acids in LS and LS + Se groups, $\mathrm{n}-6 / \mathrm{n}-3$ ratio in this groups decreased $(\mathrm{P}<0.05)$ in comparison to $\mathrm{C}$ group. Similar to this Gonthier et al. (2005.) also determined higher $\alpha$-linolenic acid in plasma of late lactating cows fed with linseed. 
Table 3. Fatty acid profile (\% of total fatty acids) in plasma of Holstein cows fed diets containing no linseed, linseed and linseed plus selenium on the $21^{\text {st }}$ day of lactation

\begin{tabular}{|c|c|c|c|c|c|c|}
\hline \multirow{2}{*}{\multicolumn{2}{|c|}{ Fatty acid }} & \multicolumn{5}{|c|}{ Dietary treatment } \\
\hline & & $\mathrm{C}$ & LS & $\mathrm{LS}+\mathrm{Se}$ & s.e.m. ${ }^{1}$ & $P$ value \\
\hline \multirow{5}{*}{ 空 } & Cl6:0 & 15.62 & 14.69 & 14.33 & 0.37 & 0.43 \\
\hline & Cl6:1 & 1.04 & 1.25 & 1.16 & 0.08 & 0.63 \\
\hline & $\mathrm{Cl} 7: 0$ & 1.90 & 1.34 & 1.30 & 0.17 & 0.32 \\
\hline & Cl7:1 & 0.19 & 0.36 & 0.49 & 0.08 & 0.41 \\
\hline & C18:0 & 15.31 & 15.99 & 15.15 & 0.62 & 0.86 \\
\hline \multirow{3}{*}{$\stackrel{5}{\Sigma}$} & Cl8: $\ln -9$ & 10.86 & 13.08 & 10.50 & 0.60 & 0.13 \\
\hline & C18:ln-7 & 1.02 & 1.28 & 1.13 & 0.07 & 0.33 \\
\hline & C20: $\ln -9$ & 1.47 & 0.97 & 1.29 & 0.18 & 0.57 \\
\hline \multirow{4}{*}{$\begin{array}{l}\mathbb{1} \\
\text { 足 } \\
0 \\
\dot{1}\end{array}$} & $\mathrm{C} 18: 2 \mathrm{n} 6$ & 40.99 & 40.79 & 42.85 & 1.29 & 0.82 \\
\hline & $\mathrm{Cl} 18: 3 \mathrm{n} 6$ & 0.81 & 0.78 & 0.87 & 0.07 & 0.91 \\
\hline & C20:3n6 & 2.09 & 2.37 & 2.55 & 0.14 & 0.50 \\
\hline & C20:4n6 & 4.60 & 3.87 & 3.89 & 0.29 & 0.58 \\
\hline \multirow{3}{*}{ 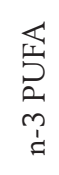 } & $\mathrm{C} 18: 3 n 3$ & $2.45^{\mathrm{a}}$ & $2.93^{b}$ & $3.04^{\mathrm{b}}$ & 0.09 & 0.01 \\
\hline & C20:5n3 & $0.31^{\mathrm{a}}$ & $0.46^{\mathrm{b}}$ & $0.51^{b}$ & 0.03 & 0.02 \\
\hline & C22:5n3 & 0.48 & 0.59 & 0.73 & 0.05 & 0.12 \\
\hline \multicolumn{2}{|r|}{$\sum$ SFA } & 32.82 & 32.02 & 30.78 & 0.82 & 0.68 \\
\hline \multicolumn{2}{|c|}{$\sum$ MUFA } & 13.11 & 15.97 & 13.28 & 0.69 & 0.15 \\
\hline \multicolumn{2}{|c|}{$\sum$ n-6 PUFA } & 48.49 & 47.81 & 50.16 & 1.21 & 0.75 \\
\hline \multicolumn{2}{|c|}{$\sum$ n-3 PUFA } & $2.93^{\mathrm{a}}$ & $3.52^{\mathrm{b}}$ & $3.77^{\mathrm{b}}$ & 0.12 & 0.01 \\
\hline \multicolumn{2}{|r|}{$n-6 / n-3$} & $16.55^{\mathrm{a}}$ & $13.58^{\mathrm{b}}$ & $13.31^{\mathrm{b}}$ & 1.16 & 0.02 \\
\hline \multicolumn{2}{|r|}{$\sum$ PUFA } & 51.73 & 51.80 & 54.44 & 0.58 & 0.65 \\
\hline \multicolumn{2}{|r|}{$\sum$ MCFA } & 18.74 & 17.64 & 17.28 & 0.45 & 0.46 \\
\hline \multicolumn{2}{|r|}{$\sum$ LCFA } & 80.40 & 82.87 & 82.08 & 0.66 & 0.33 \\
\hline
\end{tabular}

C - Control group,

LS - Linseed group,

$\mathrm{LS}+\mathrm{Se}$ - Linseed + Selenium group,

SFA - Saturated fatty acids,

MUFA - Monounsaturated fatty acids,

PUFA - Polyunsaturated fatty acids,

SCFA - Short chain fatty acids $(<\mathrm{C}: 14)$,

MCFA - medium chain fatty acids (C:14 to $<$ C:18),

LCFA - long chain fatty acids ( $>$ C:17)

${ }^{1}$ Pooled standard error of means.

\section{Milk fatty acid composition}

The proportions of milk fatty acids determined on the $21^{\text {st }}$ day of lactation are presented in Table 4. The proportions of long chain fatty acids (LCFA) and monounsaturated fatty acids (MUFA) in milk were higher $(\mathrm{P}<0.05)$ in the LS group compared to the LS+Se group. This can be mostly attributed to the proportion of oleic $\mathrm{Cl}$ 8:1 fatty acid ratio of which was significantly higher $(\mathrm{P}<0.05)$ in the LS group. Ratio of $\alpha$-linolenic acid was higher $(\mathrm{P}<0.05)$ in $\mathrm{LS}+\mathrm{Se}$ group compared to the $\mathrm{C}$ group. Ratio of both eicosapentaenoic (C20:5n-3) and docosahexaenoic $(\mathrm{C} 22: 6 n-3)$ fatty acids were higher $(\mathrm{P}<0.05)$ in $\mathrm{LS}+$ Se groups compared to the $\mathrm{C}$ and LS groups. This is in agreement with Schäfer et al. (2004) who found that Se deficiency significantly reduced levels of $\mathrm{n}-3$ series fatty acids such as docosahexaenoic (C22:6n-3) present in liver phospholipids. Ratio of $\mathrm{n}-6 / \mathrm{n}-3$ fatty acids in milk was lower $(\mathrm{P}<0.05)$ in the experimental $\mathrm{LS}+\mathrm{Se}$ group compared to the $\mathrm{C}$ and LS groups which is also in agreement with Schäfer et al. (2004) who found that due to the Se deficiency the conversion of LA to arachidonic acid was reduced and the ratio of n-6/n-3 fatty acids was increased in liver phospholipids.

The present study was designed to investigate the influence of a diet enriched with n-3 fatty acids on plasma and milk fatty acid composition of dairy cows. The addition of $\alpha$-linolenic acid in the feed of monogastric animals significantly increases the ratio of this fatty acid in the milk (Chilliard et al., 2008). Biohydrogenation of unsaturated fatty acids in rumen of polygastric animals means that it is more difficult to manipulate milk fatty acid composition (Klir et al., 2012). Feeding dairy animals with fish oil significantly increases the ratio of $n-3$ fatty acids in milk (Gallardo et al., 2014) but the problem of fish odour in the milk presents a problem for the dairy industry (Shingfield, 2005). Feeding $\alpha$-linolenic rich linseed bypassed this problem but an increase of $\mathrm{n}-3$ fatty acids in milk is not as evident as in case with fish oil addition. Metabolic concentration of $\alpha$-linolenic acid apart from intake, depends on the rate of escape from ruminal biohydrogenation. Still, different treatment of linseed (grounding, micronizing or/and extruding) can decrease biohydrogenation and increase the ratio of $n-3$ fatty acids in milk (Gonthier et al., 2005). 
Table 4. Fatty acid profile (\% of total fatty acids) in milk of Holstein cows fed diets containing no linseed, linseed and linseed plus selenium on the $21^{\text {st }}$ day of lactation

\begin{tabular}{|c|c|c|c|c|c|c|}
\hline \multirow{2}{*}{\multicolumn{2}{|c|}{ Fatty acid }} & \multicolumn{5}{|c|}{ Dietary treatment } \\
\hline & & $\mathrm{C}$ & LS & $\mathrm{LS}+\mathrm{Se}$ & s.e.m. ${ }^{1}$ & $P$ value \\
\hline \multirow{5}{*}{ 空 } & C16:0 & 15.62 & 14.69 & 14.33 & 0.37 & 0.43 \\
\hline & Cl6:1 & 1.04 & 1.25 & 1.16 & 0.08 & 0.63 \\
\hline & $\mathrm{Cl} 17: 0$ & 1.90 & 1.34 & 1.30 & 0.17 & 0.32 \\
\hline & $\mathrm{Cl} 17: 1$ & 0.19 & 0.36 & 0.49 & 0.08 & 0.41 \\
\hline & $\mathrm{Cl} 18: 0$ & 15.31 & 15.99 & 15.15 & 0.62 & 0.86 \\
\hline \multirow{3}{*}{$\sum_{\Sigma}^{J}$} & C18: $\ln -9$ & 10.86 & 13.08 & 10.50 & 0.60 & 0.13 \\
\hline & C18:ln-7 & 1.02 & 1.28 & 1.13 & 0.07 & 0.33 \\
\hline & $C 20: \ln -9$ & 1.47 & 0.97 & 1.29 & 0.18 & 0.57 \\
\hline \multirow{4}{*}{$\begin{array}{l}\mathbb{1} \\
\text { D } \\
0 \\
0 \\
1\end{array}$} & $\mathrm{Cl} 18: 2 \mathrm{n} 6$ & 40.99 & 40.79 & 42.85 & 1.29 & 0.82 \\
\hline & C18:3n6 & 0.81 & 0.78 & 0.87 & 0.07 & 0.91 \\
\hline & C20:3n6 & 2.09 & 2.37 & 2.55 & 0.14 & 0.50 \\
\hline & C20:4n6 & 4.60 & 3.87 & 3.89 & 0.29 & 0.58 \\
\hline \multirow{3}{*}{$\begin{array}{l}\overleftrightarrow{I} \\
\text { 足 } \\
m \\
\text { ? }\end{array}$} & $\mathrm{Cl} 8: 3 \mathrm{n} 3$ & $2.45^{\mathrm{a}}$ & $2.93^{\mathrm{b}}$ & $3.04^{\mathrm{b}}$ & 0.09 & 0.01 \\
\hline & C20:5n3 & $0.31^{\mathrm{a}}$ & $0.46^{\mathrm{b}}$ & $0.51^{\mathrm{b}}$ & 0.03 & 0.02 \\
\hline & C22:5n3 & 0.48 & 0.59 & 0.73 & 0.05 & 0.12 \\
\hline \multicolumn{2}{|r|}{$\sum$ SFA } & 32.82 & 32.02 & 30.78 & 0.82 & 0.68 \\
\hline \multicolumn{2}{|c|}{$\sum$ MUFA } & 13.11 & 15.97 & 13.28 & 0.69 & 0.15 \\
\hline \multicolumn{2}{|c|}{$\sum$ n-6 PUFA } & 48.49 & 47.81 & 50.16 & 1.21 & 0.75 \\
\hline \multicolumn{2}{|c|}{$\sum$ n-3 PUFA } & $2.93^{\mathrm{a}}$ & $3.52^{\mathrm{b}}$ & $3.77^{\mathrm{b}}$ & 0.12 & 0.01 \\
\hline \multicolumn{2}{|r|}{$n-6 / n-3$} & $16.55^{\mathrm{a}}$ & $13.58^{\mathrm{b}}$ & $13.31^{\mathrm{b}}$ & 1.16 & 0.02 \\
\hline \multicolumn{2}{|r|}{$\sum$ PUFA } & 51.73 & 51.80 & 54.44 & 0.58 & 0.65 \\
\hline \multicolumn{2}{|c|}{$\sum \mathrm{MCFA}$} & 18.74 & 17.64 & 17.28 & 0.45 & 0.46 \\
\hline \multicolumn{2}{|r|}{$\sum$ LCFA } & 80.40 & 82.87 & 82.08 & 0.66 & 0.33 \\
\hline
\end{tabular}

C - Control group,

LS - Linseed group,

LS + Se - Linseed + Selenium group,

SFA - Saturated fatty acids,

MUFA - Monounsaturated fatty acids,

PUFA - Polyunsaturated fatty acids,

SCFA - Short chain fatty acids (<C:14),

MCFA - medium chain fatty acids (C:14 to $<$ C:18),

LCFA - long chain fatty acids ( $>$ C:17)

${ }^{1}$ Pooled standard error of means.
The overall results in this research regarding the milk fatty acid composition of linseed fed cows agree with the results of other authors (Petit et al., 2007). The increase of PUFA and MUFA and the decrease in SFA is evident in the results of authors who fed dairy cows with linseed (Gonthier et al., 2005). In the present research the increase of PUFA ratio in milk was not as large as some other authors achieved with extruded (Moallem, 2009) or micronized linseed (Gonthier et al., 2005), but the only treatment of linseed in our case was grounding, thus the biohydrogenation might have been more extensive. Also, some authors compared milk composition after replacing saturated fats in feed with linseed (Marenjak et al., 2009; Petit et al., 2007). Consequently the observed difference was more evident in comparison to the present study in which soybean (n-6 PUFA) was replaced with linseed (n-3 PUFA).

The other problem with changing fatty acid composition of milk by manipulating feed composition rises from negative energy balance (NEB) at the start and the peak of lactation (Đidara et al., 2015). During NEB mammary gland uses plasma NEFA released from adipose tissue as a source of long chain fatty acids (LCFA) for milk fat synthesis. The fatty acids (FA) stored as triglycerides in ruminant adipose tissue are mainly C16:0, C18:0 and cis$9 \mathrm{Cl} 18: 1$, and are dependent on nutritional history of the cow (Chilliard et al., 2000). This means that fatty acids determined in plasma and milk on $21^{\text {st }}$ day of lactation came not only from dietary source but also from fat storages filled in previous lactation. This might be explanation for lower PUFA and $\alpha$-linolenic response in linseed supplemented groups compared to the researh of Gonthier et al. (2005) done on late lactation cows which are no more in NEB.

In our research we have determined an increase $(\mathrm{P}<0.05)$ of $\alpha$-linolenic acid both in plasma and milk of LS + Se group compared to the $\mathrm{C}$ group. Unlike to this only plasma $\alpha$-linolenic acids was higher in LS group compared to $\mathrm{C}$ group. Although $\alpha$-linolenic acid ratio in milk was higher in LS group compared to the $\mathrm{C}$ group post hoc test did not show significant difference. 
Significantly higher $(\mathrm{P}<0.05)$ was the ratio of milk oleic fatty acid in LS group compared to the both $\mathrm{C}$ and LS + Se groups. That difference was not significant in plasma, but trend towards it $(\mathrm{P}=0.13)$ could be observed. Fatty acids absorbed in the duodenum were esterified in enterocytes but prior to that stearic acid (C18:0) within the enterocytes might have been desaturated to oleic acid (cis-9 C18:1). We found it difficult to explain what has happened in the milk gland in the absence of the organic selenium and why the conversion of other fatty acids toward oleic fatty acid was so extensive. Contrary to other ruminant tissues, the lactating mammary gland was not able to convert $\mathrm{C} 16: 0$ to $\mathrm{C} 18: 0$ by chain elongation (Chilliard et al., 2000). However, fully differentiated mammary secretory cells express a high delta- 9 desaturase activity, which converts stearic acid to oleic acid. The mammary gland transforms C18:0 into cis-9 C18:1 and contributes to $60 \%$ to 80 $\%$ of the entire amount of oleic acid secreted in milk (Shingfield et al., 2013). The delta-9 desaturase activity could be inhibited by PUFA as well as by cyclopropenoic fatty acids (Chilliard et al., 2000). Although not significantly higher $(\mathrm{P}>0.05)$ ratio of PUFA was numerically $3 \%$ higher in the LS+Se group compared to the LS group, which might be the reason that blocked more extensive delta-9 desaturase activity and increase of oleic fatty acid in the LS+Se group. It is known that selenium supplement significantly increases the concentration of PUFA in breast milk (Dodge, et al., 1999). PUFA are particularly susceptible to oxidation due to the double bonds in the fatty acids. Selenium as an integral component of the enzyme glutathione peroxidase GSH-Px has a biological role as antioxidant, therefore Se could inhibit the oxidation of the oxidative-labile PUFA. It is possible that organic source of dietary Se increased plasma content of PUFA and inhibited that way the delta-9 desaturase activity. The contribution from mobilized oleic acid in early lactation and/or in negative energy balance must also be taken into account since as stated before oleic fatty acid is one of the major stored fatty acids in ruminants (Ozcan et al., 2015)

Since no statistical difference of fatty acid ration between LS and LS + Se group was evident in plasma, we can presume that major difference between ratios of some fatty acids in milk was due to the metabolic changes in the milk gland.

\section{Conclusions}

Feeding dairy cows during transition period with linseed acted positively on milk fatty acid composition by increasing the ratio of $n-3$ fatty acids. Increase of $\alpha$-linolenic fatty acid ratio in blood of both groups fed with linseed but only significant increase in milk of group supplemented with the organic selenium means that addition of the organic selenium acted favourable on $\alpha$-linolenic fatty acid increase in milk. During early postpartum period dietary $n-3$ fatty acids have increased ratio of oleic acid in milk, but in combination with the organic source of selenium this increase was not evident.

\section{Sastav masnih kiselina u plazmi i mlijeku holstein krava hranjenih dodatkom lanenog sjemena i organskog selena}

\section{Sažetak}

Laneno sjeme je krmivo bogato n-3 masnim kiselinama, ali veliki udio nezasićenih masnih kiselina može povećati lipidnu peroksidaciju. Selen, kao mikroelement, koji je nužan za normalno funkcioniranje andioksidativne obrane, može se koristiti kao aditiv kako bi se smanjila oksidacija masnih kiselina. Organski oblici selena imaju veću bioraspoloživost u odnosu na anorganske oblike. Cilj ovoga istraživanja bio je utvrditi utjecaj zamjene dijela $n-6$ masnih kiselina obroka sa $\mathrm{n}-3$ polinezasićenim masnim kiselinama na masnokiselinski sastav krvne plazme i mlijeka mliječnih krava. Pokus je proveden na 30 krava pasmine holštajn u razdoblju od partusa do 21 . dana laktacije. Sojina sačma iz kontrolne (C) skupine zamijenjena je lanenim sjemenom u pokusnim (LS i LS + Se) skupinama. Uz to anorganski oblik selena iz premiksa 2. pokusne skupine (LS+Se) zamijenjen je keliranim oblikom selena. U uzorcima krvi i mlijeka prikupljenih 21. dana laktacije određen je sastav masnih kiselina. Dodatak lanenoga sjemena u hranidbi krava tijekom prijelaznoga razdoblja povećao je $(\mathrm{P}<0,05)$ udio n-3 masnih kiselina u mlijeku. Udio $\alpha$-linolenske masne kiseline bio je značajno veći $(\mathrm{P}<0,05)$ u krvnoj plazmi obje pokusne skupine, dok je značajno $(\mathrm{P}<0,05)$ povećanje udjela iste masne kiseline utvrđeno $\mathrm{u}$ mlijeku pokusne skupine LS + Se. Dodatak lanenog sjemena tijekom prijelaznog razdoblja povećao je $(\mathrm{P}<0,05)$ udio oleinske 
masne kiseline $\mathrm{u}$ pokusnoj LS skupini $\mathrm{u}$ odnosu na kontrolnu (C) skupinu, ali ne i u odnosu na pokusnu LS + Se skupinu $(\mathrm{P}>0,05)$.

Ključne riječi: mliječne krave, laneno sjeme, masne kiseline, sastav mlijeka

\section{References}

1. Antunović, Z., Klapec, T., Ćavar, S., Šperanda, M., Pavić, V., Novoselec, J., Klir, Ž. (2013): Status of selenium and correlation with blood GSH- Px in goats and their kids in organic breeding fed with different levels of organic selenium. Archiv für Tierzucht 56 (16), 169-177.

2. AOAC (1995): Official Methods of Analysis, 2 vol., 16th edition. Association of Official Analytical Chemist Inc., Arlington, VA, USA.

3. AOAC (2000): Official Methods of Analysis, 2 vol., 17 th edition. Association of Official Analytical Chemist Inc., Arlington, VA, USA.

4. Chilliard, Y., Bauchart, D., Lessire, M., Schmidely, P., Mourot, J. (2008): Qualité des produits: modulation par l'alimentation des animaux de la composition en acides gras du lait et de la viande. Inra Productions Animales 21, 95-106.

5. Chilliard, Y., Ferlay, A., Mansbridge, M.R., Doreu, M. (2000): Ruminant milk fat plasticity: nutritional control of saturated, polyunsaturated, trans and conjugated fatty acids. Annales De Zootechnie 49, 181-205. https://doi.org/10.1051/animres:2000117

6. Chung, J.Y., Kim, J.H., Ko, Y.H., Jang, I.S. (2007): Effects of dietary supplemented inorganic and organic selenium on antioxidant defense systems in the intestine, serum, liver and muscle of Korean native goats. AsianAustralasian Journal of Animal Sciences 20 (1), 52-59. https://doi.org/10.5713/ajas.2007.52

7. Đidara, M., Poljičak-Milas, N., Milinković-Tur, S., Mašek, T., Šuran, J., Pavić, M., Kardum, M., Šperanda, M. (2015): Immune and oxidative response to linseed in the diet of periparturient Holstein cows. Animal 9 (8), 1349-1354. https://doi.org/10.1017/s1751731115000439

8. Dodge, M.L., Wander, R. C., Butler, J.A., Du, S.H., Thomson, C.D., Whanger, P.D. (1999): Selenium supplementation increases the polyunsaturated fatty acid content of human breast milk. The Journal of Trace Elements in Experimental Medicine 12 (1), 37-44. https://doi.org/10.1002/(SICI) 1520-670X(1999) $12: 1<37::$ AID-JTRA4 $>3$.0.CO;2-H

9. Gallardo, B., Gómez-Cortés, P., Mantecón, A.R., Juárez, M., Manso, T., de la Fuente, M.A. (2014): Effects of olive and fish oil $\mathrm{Ca}$ soaps in ewe diets on milk fat and muscle and subcutaneous tissue fatty-acid profiles of suckling lambs. Animal, 8 (7), 1178-1190. https://doi.org/10.1017/s1751731114000238

10. Gantner, V., Mijić, P., Baban, M., Škrtić, Z., Turalija, A. (2015): The overall and fat composition of milk of various species. Mljekarstvo 65 (4), 223-231.
11. Gonthier, C., Mustafa, A.F., Ouellet, D.R., Chouinard, P.Y., Berthiaume, R., Petit, H. V. (2005): Feeding micronized and extruded flaxseed to dairy cows: Effects on blood parameters and milk fatty acid composition. Journal of Dairy Science, 88, 748-756. https://doi.org/10.3168/jds.S0022-0302(05)72738-7

12. Haug, A., Hostmark, A.T., Harstad, O.M. (2007): Bovine milk in human nutrition - a review, Lipids in Health and Disease, 6 (25), 1-16. https://doi.org/10.1186/1476-511X-6-25

13. Klir, Ž., Antunović, Z., Novoselec, J. (2012): Utjecaj hranidbe koza na sadržaj masnih kiselina u mlijeku. Mljekarstvo 62 (4), 231-240.

14. Lourenço, M., Ramos-Morales, E., Wallace, R.J. (2010): The role of microbes in rumen lipolysis and biohydrogenation and their manipulation. Animal, 4, 1008-1023. https://doi.org/10.1017/S175173111000042X

15. Marenjak, T.S., Delaš, I., Poljičak-Milas, N. (2009): The milk fatty acid composition and production in Simmental cows supplemented with unprotected sunflower oil in the ration. Milchwissenschaft 64 (2009), 3; 235-238.

16. Moallem, U. (2009): The effects of extruded flaxseed supplementation to high-yielding dairy cows on milk production and milk fatty acid composition. Animal Feed Science and Technology 152, 232-242. https://doi.org/10.1016/j.anifeedsci.2009.04.018

17. Ozcan, T., Yaslioglu, E., Kilic, I., Simsek, E. (2015): The influence of the season and milking time on the properties and the fatty acid composition of the milk in different dairy cattle farms. Mljekarstvo 65 (1), 9-17. https://doi.org/10.15567/mljekarstvo.2015.0102

18. Petit, H.V., Palin, M.F., Doepel, L. (2007): Hepatic Lipid Metabolism in Transition Dairy Cows Fed Flaxseed. Journal of Dairy Science 90, 4780-4792. https://doi.org/10.3168/jds.2007-0066

19. Rule, D.C. (1997): Direct transesterification of total fatty acids of adipose tissue, and of freeze-dried muscle and liver with borontrifluoride in methanol. Meat Science 46 (1): 23-32. https://doi.org/10.1016/S0309-1740(97)00008-9

20. Schäfer, K., Kyriakopoulosb, A., Gessnerb, H., Grunec, T., Behneb, D. (2004): Effects of selenium deficiency on fatty acid metabolism in rats fed fish oil-enriched diets. Journal of Trace Elements in Medicine and Biology 18, 89-97. https://doi.org/10.1016/j.jtemb.2004.03.003

21. Scholljegerdes, E.J., Lekatz, L.A., Vonnahme, K.A. (2014): Effects of short-term oilseed supplementation on plasma fatty acid composition, progesterone and prostaglandin F metabolite in lactating beef cows. Animal 8, 777-785. https://doi.org/10.1017/S1751731114000263

22. Shingfield, K.J., Bonnet, M., Scollan, N.D. (2013): Recent developments in altering the fatty acid composition of ruminant-derived foods. Animal 7, 132-162. https://doi.org/10.1017/S1751731112001681

23. Shingfield, K.J., Reynolds, C.K., Lupoli, B., Toivonen, V., Yurawecz, M.P., Delmonte, P., Griinari, J.M., Grandison, A.S., Beever, D.E. (2005): Effect of forage type and proportion of concentrate in the diet on milk fatty acid composition in cows fed sunflower oil and fish oil. Journal of Animal Science 80, 225-238. 